\title{
Gerberan karvasaineet suojaavat hyönteisherbivorialta
}

\author{
Ulla Anttila, Paula Elomaa, Heikki Hokkanen ja Teemu Teeri \\ Soveltavan biologian laitos, Latokartanonkaari 5-7, 00014 Helsingin yliopisto, ulla.anttila \\ @ helsinki.fi, paula.elomaa@helsinki.fi, heikki.hokkanen@helsinki.fi, teemu.teeri@helsinki.fi
}

\section{Tiivistelmä}

Gerbera hybrida (sädelatva) on suosittu koristekasvi. Terälehtien värit ovat peräisin vesiliukoisista antosyaaneista, jotka ovat sekundäärimetabolian tuotteita. Tutkiessamme tätä metaboliareittiä, löysimme sen läheltä haaran, joka johtaa karvaan makuisiin yhdisteisiin, gerberiiniin ja parasorbosidiin. Näiden karvasaineiden merkitys gerberalle on ollut tuntematon.

Gerberan karvasaineiden biosynteesiin vaikutettiin geenitekniikan keinoin hiljentämällä keskeisen 2PS-geenin toiminta. Anti-2PS-linjojen siirtogeenisiin gerberoihin ei gerberiiniä ja parasorbosidia synny, vaan ne maistuvat tavanomaiseen gerberaan verrattuna makealta. Epäily näiden makealta maistuvien kasvien herkkyydestä hyönteisherbivoriaan heräsi kasvihuonehavaintojemme perusteella.

Teimme erilaisia syöttö- ja munintakokeita, joissa hyönteiset saivat valita karvasaineettoman ja karvasainetta sisältävän gerberan välillä. Karvasaineilla oli voimakas estävä vaikutus täplätupsukkaan (Orgyia antiqua) ja krysanteemiyökkösen (Spodoptera littoralis) herbivoriaa vastaan. Ansarijauhiasen (Trialeurodes vaporariorum) toukille karvasaineilla ei ollut merkitystä.

Tutkimuksemme perusteella karvasaineilla on hyönteisherbivoriaa ehkäisevä vaikutus. Eri lajikkeilla on vaihtelua karvasaineiden määrän suhteen ja yhdisteiden pitoisuuksien mittaaminen on yksinkertainen keino uusien lajikkeiden hyönteiskestävyyden arvioimiseen jalostustyössä. Pitkällä tähtäyksellä on myös mahdollista molekyylibiologisin keinoin siirtää koko karvasainereitti uusiin hyötykasvilajeihin, käytännössä koristekasveihin.

Asiasanat: karvasaineet, herbivoria, gerbera 


\section{Johdanto}

Koristekasvina suosittu sädelatva (Gerbera hybrida) on tunnettu laajasta värikirjostaan ja joka vuosi markkinoille tulevista uusista lajikkeista, joiden terälehdissä hehkuvat punaiset, oranssit ja keltaiset sävyt. Punaiset ja oranssit värit ovat peräisin vesiliukoisista antosyaaneista. Selvittäessämme antosyaanien biosynteesiä gerberassa, löysimme metabolian haaraan, joka johtaa karvaan makuisiin yhdisteisiin gerberiiniin ja parasorbosidiin. Antosyaanien biosynteesissä tärkeän kalkonisyntaasin geeni on evoluution kuluessa kahdentunut ja toinen kopio on saanut uuden funktion. Näin syntynyt 2pyronisyntaasi (2PS) vastaa karvasaineiden biosynteesin ensimmäisestä vaiheesta (Helariutta et al. 1995, Helariutta et al. 1996, Eckermann et al. 1998).

Karvasaineita kertyy gerberassa lähes kaikkiin maanpäällisiin osiin (Nagumo et al. 1985). Aineiden biologisen funktion selvittämiseksi siirsimme 2PS geenin takaisin gerberaan käännettynä, jolloin siirtogeeni esti 2PS entsyymin muodostumisen. Jalostetun anti-2PS -lajikkeen ulkonäössä ei tapahtunut muutosta, mutta ne lakkasivat muodostamasta gerberiiniä ja parasorbosidia (Elomaa et al. 1996).

Kasvihuonehavaintojen perusteella huomattiin siirtogeenisten anti-2PS -linjojen houkuttelevan ripsiäisiä. Tästä heräsi olettamus, että karvasaineilla voisi olla hyönteisherbivorialta suojaava vaikutus. Tämän tutkimuksen tavoitteena oli selvittää, onko karvasaineilla hyönteisherbivoriaa vähentävä vaikutus ja muuttaako karvasaineiden täsmäpoisto gerberan alttiutta hyönteisherbivoriaan.

\section{Aineisto ja menetelmät}

Kokeet tehtiin Regina-lajikkeesta johdetuilla siirtogeenisillä anti-2PS gerberalinjoilla no. 4 ja 5 käyttäen kontrollina ei-siirtogeenistä Regina-lajikkeen gerberaa. Koehyönteisinä käytettiin kolmea eri hyönteistä, jotka olivat täplätupsukas Orgyia antiqua, krysanteemiyökkönen Spodoptera littoralis sekä ansarijauhiainen Trialeurodes vaporariorum. Kaikki kolme ovat merkittäviä gerberan tuholaisia. Krysanteemiyökkönen ja täplätupsukas syövät gerberan koko lehtimassaa ja ansarijauhiainen imee kasvinesteitä lähinnä lehtien alapinnoilta.

Kasvien gerberiini- ja parasorbosidipitoisuudet mitattiin uuttamalla pakastekuivatut lehtinäytteet metanolilla ja analysoimalla uutteet ohutlevykromatografialla (Yrjönen et al. 2002). Glukosidit tunnistettiin kastamalla levy $15 \%$ rikkihappoon metanolissa ja lämmittämällä levyä $10 \min 120^{\circ} \mathrm{C}$.

Krysanteemiyökkösen ja täplätupsukkaan toukilla kokeet tehtiin valintasyöttökokeena petrimaljoilla laboratoriossa. Kokeilla seurattiin niiden syömishalukkuutta anti-2PS-kasvin ja kontrollin välillä. Kokeissa vedellä kostutettu suodatinpaperi asetettiin maljalle. Maljalle asetettiin saman painoiset palat testikasvin ja kontrollikasvin lehteä. Keskelle maljaa asetettiin toukka. Toukka sai valita syötäväkseen joko testi- tai kontrollikasvin lehteä. Kokeen aikana toukan syöntiä seurattiin lehden painoa mittaamalla $(\mathrm{g})$ tai aistinvaraisesti arvioimalla toukan lehden syöntiä $\left(\mathrm{cm}^{2}\right)$. Täplätupsukkaan toukilla tehtiin viisi koetta $(n=8-12)$. Krysanteemiyökkösen toukilla tehtiin seitsemän valintasyöttökoetta ja yksi pakkosyöttökoe, jossa toukalle tarjottiin joko testi tai kontrollikasvia $(n=10-12)$.

Akvaariokokeessa seurattiin aikuisten ansarijauhiaisten asettumista anti-2PS-kasvien ja kontrollikasvien välillä. Yhdeksään akvaarioon laitettiin maljakoihin sekä koekasvin että kontrollikasvin lehtiä. Akvaarioihin lisättiin n. 50 aikuista ansarijauhiaista ja niiden asettumista ja oleskelua joko testi- tai kontrollikasvin lehdillä seurattiin 15 vrk:n ajan.

Muut ansarijauhiaiskokeet tehtiin kasvihuoneolosuhteissa ns. pussikokeina. Ansarijauhiaisten munintahalukkuutta selvittävä koe siirtogeenisten ja kontrollikasvien välillä tehtiin pussikokeena kasvihuoneella. Emokasveissa kiinni olevia testi- ja kontrollikasvin lehtiä pussitettiin harsopusseihin yksitellen kahdeksan kappaletta kumpaakin (Kuva 3b). Pussin sisälle laitettiin n. 20 aikuista ansarijauhiaista, jonka jälkeen pussi suljettiin. Kuukauden kuluttua pussi avattiin ja munat, toukat ja valekotelot laskettiin.

Pussikoe tehtiin myös valintakokeena, jossa aikuiset ansarijauhiaiset saivat valita oleskelu- ja munintapaikkansa koe- ja kontrollilehden välillä. Testi- ja kontrollikasvit aseteltiin ruukkuineen rintarinnan, jotta 16:sta harsopussiin saatiin sekä testikasvin että kontrollikasvin lehti, sekä 20 ansarijauhiaista. Kuukauden kuluttua pussit avattiin ja aikuisten, munien, toukkien ja valekoteloiden määrät kummallakin lehdellä laskettiin. Ennen jokaista ansarijauhiaiskoetta kokeeseen osallistuvat lehdet harjattiin pullasudilla puhtaiksi munista.

\section{Tulokset}


Kokeessa käytettyjen siirtogeenilinjojen gerberiini- ja parasorbosidipitoisuudet määritettiin kokeeen alussa ohutlevykromatografialla. Nämä kaksi karvasainetta oivat gerberan runsaimpia uuteaineita ja ne puuttuivat kokonaan tai lähes kokonaan anti-2PS linjoista 4 ja 5 (Kuva 1).

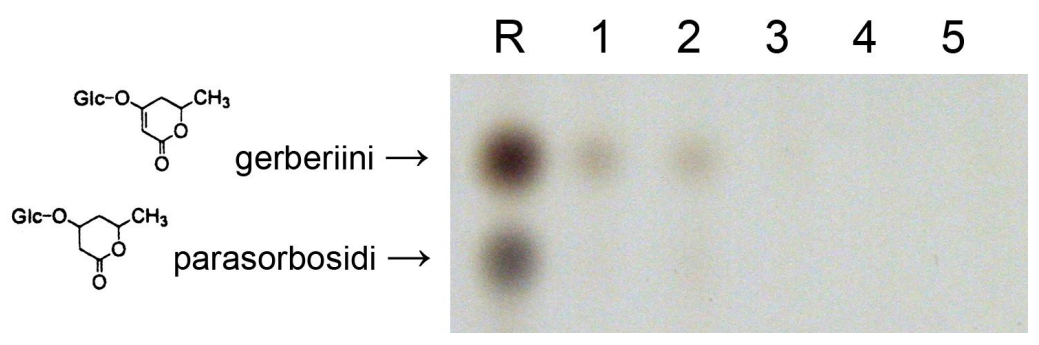

Kuva 1. Transgeenisten linjojen (no. 1-5) gerberiini- ja parasorbosidipitoisuudet verrattuna ei-siirtogeeniseen Regina-lajikkeeseen (R).

Krysanteemiyökkösellä ja täplätupsukkaalla nähtiin selvä ero toukkien syönnissä karvasaineiden pitoisuuden mukaan. Krysanteemiyökkönen söi kaikissa kokeissa huomattavasti enemmän anti-2PS kasveja, joista karvasaineet oli poistettu (Kuva 2a, b). Samoin täplätupsukkaan toukan syöttökokeissa toukat söivät huomattavasti enemmän makeaksi muutettua anti-2PS-kasvia kuin karvaan makuista kontrollikasvia (Kuva 2c). Kaikkien tehtyjen kokeiden tulokset olivat samansuuntaiset. Pakkosyöttökokeen lopussa osa pelkällä kontrollikasvilla eläneistä toukista kuoli, oletettavasti nälkään koska kasviin ei oltu juuri edes koskettu ja muuta ravintoa ei ko. toukille ollut tarjolla.
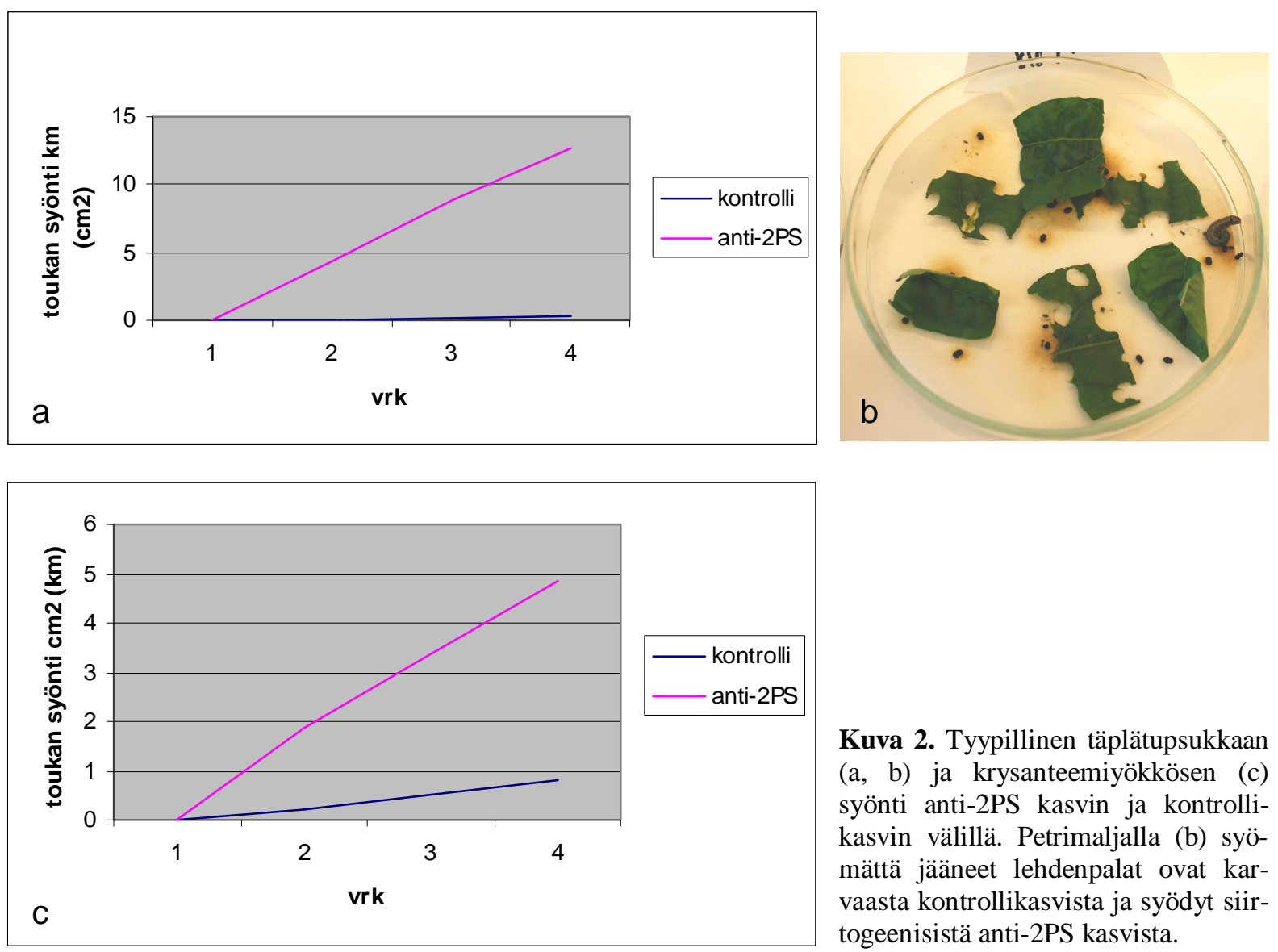

Kuva 2. Tyypillinen täplätupsukkaan (a, b) ja krysanteemiyökkösen (c) syönti anti-2PS kasvin ja kontrollikasvin välillä. Petrimaljalla (b) syömättä jääneet lehdenpalat ovat karvaasta kontrollikasvista ja syödyt siirtogeenisistä anti-2PS kasvista. 
Akvaariokokeissa ansarijauhiaisille kelpasi oleilupaikaksi sekä anti-2PS lehti että kontrollilehti (Kuva 3a). Merkittävää eroa lehtien välillä ei ollut. Aikuiset ansarijauhiaiset eivät juuri liikkuneet kokeen aikana, vaan ne tyytyivät lehteen, jonka olivat aluksi valinneet. Ansarijauhiaiset myös asettuivat lehdille toistensa läheisyyteen, eivätkä tasaisesti kaikille akvaariossa oleville lehdille. Hajonta akvaarioiden välillä oli suurta.
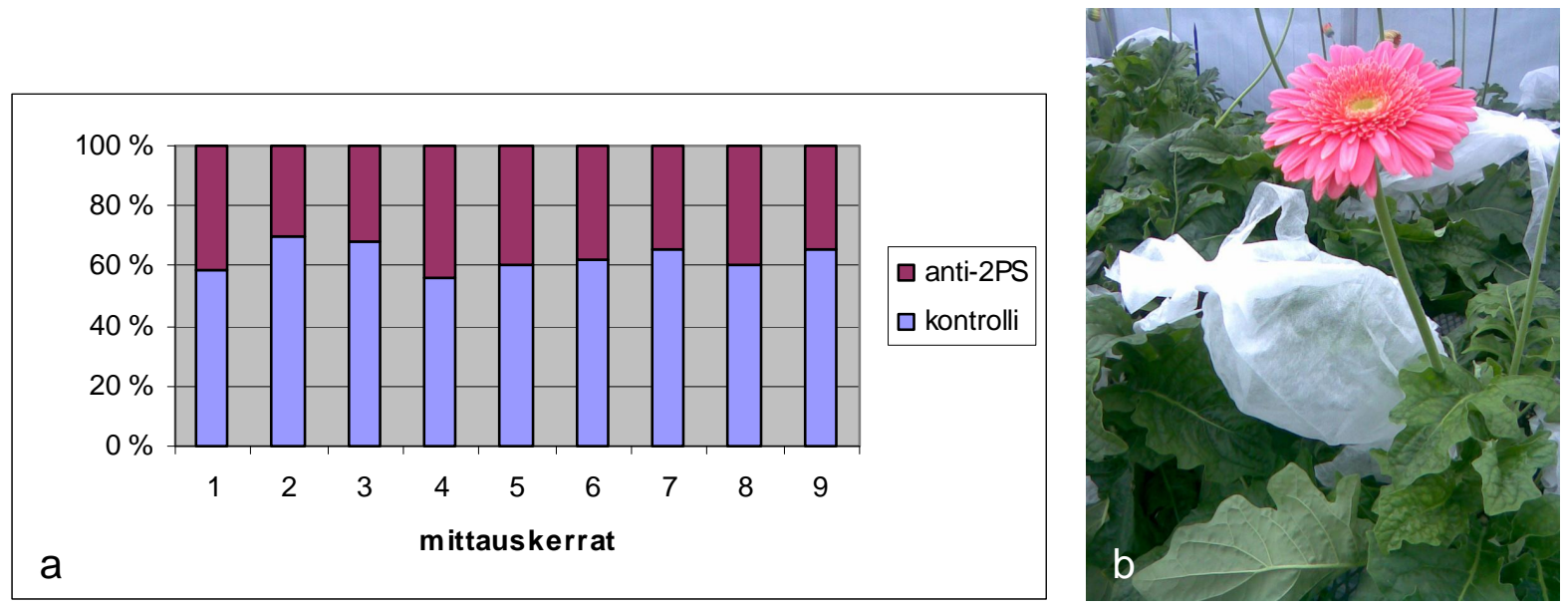

Kuva 3. Ansarijauhiasten asettuminen anti-2PS-kasvin ja kontrollikasvin lehdille akvaariokokeessa (a). Jauhiaiset eivät tehneet eroa karvaiden ja makeiden linjojen välillä. Samanlainen tulos saatiin kasvihuoneella tehdyssä harsopussikokeessa (b).

Ansarijauhiaisten pakkosyöttönä tehdyssä pussikokeessa (Kuva 3b) jauhiaiset olivat munineet vain hieman enemmän niissä pusseissa, joissa oli anti-2PS kasvin lehti. Näissä pusseissa oli kokeen loputtua enemmän munia ja toukkia. Myös kontrollikasvin lehti oli kelvannut muninta-alustaksi.

Valintakokeena tehdyssä pussikokeessa, jossa samassa pussissa oli sekä testi- että kontrollikasvin lehti, ansarijauhiainen oli muninut enemmän kontrollikasville kuin anti-2PS-kasville. Kontrollikasvissa oli enemmän munia ja toukkia. Pussikokeessa, jossa ansarijauhiaiset saivat valita kahden kokonaisen anti-2PS-kasvin ja kokonaisen kontrollikasvin välillä, ansarijauhiaiset oleilivat ja munivat satunnaisesti kaikilla kasveilla. Mikään kasvi ei ollut toistaan suositumpi.

\section{Tulosten tarkastelu}

Laboratoriossa tehtyjen syöttökokeiden perusteella karvasaineet estivät voimakkaasti täplätupsukkaan (Orgyia antiqua) ja krysanteemiyökkösen (Spodoptera littoralis) herbivoriaa. Ansarijauhiaseen (Trialeurodes vaporariorum) puolestaan gerberiinillä ja parasorbosidilla ei ollut vaikutusta, ne söivät ja munivat yhtä hyvin niin karvaita kuin makeaksi muunneltuja gerberan lehtiä.

Gerberiinin ja parasorbosidin biologinen funktio gerberassa on tähän asti ollut arvoitus. Eri lajikkeilla on vaihtelua karvasaineiden määrän suhteen ja yhdisteiden pitoisuuksien mittaaminen on yksinkertainen keino uusien lajikkeiden hyönteiskestävyyden arvioimiseen jalostustyössä. Pitkällä tähtäyksellä on myös mahdollista molekyylibiologisin keinoin siirtää koko karvasainereitti uusiin hyötykasvilajikkeisiin, käytännössä koristekasveihin. 


\section{Kirjallisuus}

Eckermann, S., Schröder, G., Schmidt, J., Strack, D., Edrada, R.A., Helariutta, Y., Elomaa, P., Kotilainen, M., Kilpeläinen, I., Proksch, P., Teeri, T.H. \& Schröder, J. 1998. New pathway to polyketides in plants. Nature, 396: 387-390.

Elomaa, P., Helariutta, Y., Kotilainen, M. \& Teeri, T.H. 1996. Transformation of antisense constructs of the chalcone synthase gene superfamily into Gerbera hybrida: differential effect on the expression of family members. Molecular Breeding, 2: 41-50.

Helariutta, Y., Elomaa, P., Kotilainen, M., Griesbach, R.J., Schröder, J. \& Teeri, T.H. 1995. Chalcone synthase-like genes active during corolla development are differentially expressed and encode enzymes with different catalytic properties in Gerbera hybrida (Asteraceae). Plant Mol. Biol. 28: 47-60.

Helariutta, Y., Kotilainen, M., Elomaa, P., Kalkkinen N., Bremer, K., Teeri, T.H. \& Albert, V. 1996. Duplication and functional divergence in the chalcone synthase gene family of Asteraceae: evolution with substrate change and catalytic simplification. Proc. Natl. Acad. Sci. U.S.A., 93: 9033-9038.

Nagumo S, Imamura K, Inoue T \& Nagai M. 1985. Cyanogenic glycosides and 4-hydroxycoumarin glycosides from Gerbera jamesonii hybrida. Chem Pharm Bull 33: 4803-4906.

Yrjönen, T., Vuorela, P., Klika, K.D., Pihlaja, K., Teeri, T.H. \& Vuorela, H. 2002. Application of centrifugal force to the extraction and separation of parasorboside and gerberin from Gerbera hybrida. Phytochemical Analysis 13: $349-353$ 